\title{
Description of four cases of death by methanol: the experience of the toxicology and pharmacology laboratory of Moroccan Poison Control Centre
}

\author{
Naima Aït daoud ${ }^{1,2}$, Mohamed Ghandi ${ }^{1,3}$, Hanane Chaoui ${ }^{1}$, Omaima El Bouazzi ${ }^{1.2}$, Fatima Zalagh ${ }^{1}$, Asma Abkari ${ }^{1}$, \\ Abdelmajid Soulaymani ${ }^{2}$,Rachida Soulaymani Bencheikh ${ }^{1,4}$, Narjis Badrane ${ }^{1,2}$ and Doha Benali ${ }^{2}$ \\ ${ }^{1}$ Toxicology and Pharmacology Laboratory, Anti Poison and Pharmacovigilance Centre of Morocco \\ ${ }^{2}$ Faculty of Sciences of Kenitra, Ibn Tofail University, Morocco \\ ${ }^{3}$ Faculty of Sciences of Rabat, Mohammed V Souissi University, Morocco \\ ${ }^{4}$ Faculty of Medicine and Pharmacy of Rabat, Mohammed V Souissi University, Morocco
}

\begin{abstract}
Introduction: Methanol intoxication is a public health problem that mainly affects poor populations in developed and developing countries. Despite all the advanced treatment methods, high mortality rates are still observed due to late admission to hospital and late diagnosis and treatment. Many mass poisoning have been described, following the misuse of methanol in the manufacture of adulterated alcohol in some Eastern European, Asian and African countries, resulting in several hundred each year. Objective: The objective of our study was to describe four cases of methanol intoxication that were received by the au toxicology and pharmacology laboratory of the Moroccan poison control centre CAPMLAB. Materiel and methods: The epidemiological characteristics of patients intoxicated and dying by methanol in a collective setting were described as well as the results. Ethanol and methanol were determined in whole blood by gas chromatography with a flame ionisation detector coupled to the Head speace (CPG-FID-HS). Results: Following the consumption of adulterated alcohol (locally prepared alcohol); the CAPM-LAB received three samples from the city of El-Hajeb. The patients were aged of 46, 58 and 26 years and presented visual and consciousness disorders and vomiting, they presented average methanolemia of $1,34 \mathrm{~g} / \mathrm{l}$. The CAPM-LAB also received samples from another patient from the city of Marrakech, aged 44 years, following a collective intoxication (three people) with adulterated alcohol, with methanol level of 2,52g/l. The patients died as a result of heart failure. Conclusion: Methanol can cause fatal intoxication, due to its easy availability in our country and the illegal production of alcoholic beverages.
\end{abstract}

Key words: Mass poisoning, death, methanol dosage, adulterated alcohol.

\section{Introduction}

Methanol intoxication following the consumption of adulterated alcohol is a real health problem throughout the world; especially in developing countries were methanol is responsible for real collective intoxications that can be potentially serious [1]. Methanol (also known as methyl alcohol and wood alcohol) is a kind of alcohol, with a significant role as a precursor for chemical synthesis and solvents (used in making various pain and stain removers, car glass washing liquids, anti freeze, cologne and spirits. Exposure to methanol may be inadvertent through accidental ingestion or through occupational hazards via inhalation, dermal absorption, or ingestion. Alternatively, methanol may be ingested with the intention to commit suicide. Acute intoxication is caused by the ingestion of methanol (e.g. fraudulent substitution of ethyl alcohol with methanol). Accidental or intentional methanol intoxication is a

*Corresponding author: naimaaitdaoud@yahoo.fr 
potential cause of severe metabolic acidosis. Coma, visual impairment and severe metabolic acidosis are the most common complications of this intoxication $[2,3,4,5]$.

In Morocco, the Moroccan Anti Poison and pharmacovigilance Centre (CAPM) has recorded several episodes of methanol intoxication (9 deaths in 1997, 2 deaths in 2005 and 4 deaths in 2008 with one case of blindness) [6].

In the case of methanol intoxication, the contribution of the laboratory is essential to help the clinician in his diagnostic and therapeutic approach [7]. Rapid diagnostic is essential because the patient's vital prognosis is at risk with a mortality rate of $89 \%$ if the initial $\mathrm{pH}$ is below 7 [8]. Toxicological analysis also allows the management of the antidotic use (fomepizole or ethanol) and purifying treatment, and its early initiation to improve the vital prognosis.

Gas chromatography remains the reference method for ethanol and methanol determination [9]. This technique is used at CAPM-LAB for the determination of methanol in intoxicated patients. In this context, the objective of this work was to show the interest of methanol dosage in the management of collective intoxications by this alcohol by describing four cases of death by methylated spirits intoxication, which occurred in two regions of El Hajeb and Marrakech.

\section{Materiel and methods}

We conducted a retrospective descriptive study of methanol assay requests from CAPM-LAB from January 2016 to March 2018.

The tests are carried out at the CAPM-LAB following suspected acute methanol intoxication in hospitalized patients, or as part of investigations carried out by the CAPM toxicovigilance team following a collective intoxication. The CAPM-LAB also analyses incriminated products.

Blood and urine samples from four patients were sent to the toxicology and pharmacology laboratory of the Moroccan Poison and Pharmacovigilance Centre (CAPM-LAB) in the province of Hajeb and Marrakech.

The alcohols, specifically ethanol and methanol, were measured.

The sample is taken on an EDTA (Ethylene Diamine Tetra-Acetic) tube and one $\mathrm{ml}$ of whole blood is required for assay and confirmation.

The method for determination of ethanol and methanol was validated at CAPM-LAB on whole blood using GC gas chromatography (Agilent 6890N) with a «Headspace» injector (7694E), coupled to the flame ionisation detector (FID). The capillary column used is RTX type ( $30 \mathrm{~m}^{*} 0.32$ ID $\left.0.25 \mathrm{um}\right)$. The data acquisition and processing system is obtained using Chemstation software (REV A.10.02). The detection limit is $0,1 \mathrm{~g} / 1$.

This technique is the most appropriate for the analysis of alcohols.

\section{Results}

The CAPM-LAB performed a total of 41 methanolemias between 2016 and 2018 and four analyses of the incriminated products. The majority of patients were male (four females in total). The average age of the patients was de $32 \pm 14,85$ years. $87,8 \%$ of patients (37 cases) had a methanol level of less than 0,1 $\mathrm{g} / 1$ and 4 patients had a mean methanol level of 1,27 g/l. CAPM-LAB also participated in investigations related to collective methanol intoxications in the city of El-Hajeb and the region of Marrakech.

Episode of intoxication in El Hajeb:

Twenty young patients presented visual disorders, neurological signs and vomiting, with 3 deaths following the ingestion of counterfeit alcohol, during May 2017. The CAPM-LAB received from the city of El-Hajeb blood samples from 3 persons who presented visual disorders, consciousness disorders and vomiting evolving towards death, as well as four methanol products incriminated in the intoxication (table I).

The present results show that the young men are the major patients suffer from methanol poisoning.

Table I: Description of the three cases from the city of ElHajeb

\begin{tabular}{|c|c|c|c|}
\hline Data & 1st case & 2nd case & 3rd case \\
\hline Gender & M & $\mathrm{M}$ & M \\
\hline Age & 26 & 46 & 58 \\
\hline $\begin{array}{c}\text { Time to } \\
\text { intoxication }\end{array}$ & $6 \mathrm{H}$ & $7 \mathrm{H}$ & $8 \mathrm{H}$ \\
\hline $\begin{array}{l}\text { Digestive } \\
\text { symptoms }\end{array}$ & $\begin{array}{c}\text { Nausea } \\
\text { Digestive } \\
\text { pain } \\
\text { Dry mouth }\end{array}$ & $\begin{array}{c}\text { Nausea } \\
\text { Digestive } \\
\text { pain } \\
\text { Dry mouth }\end{array}$ & $\begin{array}{c}\text { Nausea } \\
\text { Digestive } \\
\text { pain } \\
\text { Dry mouth }\end{array}$ \\
\hline $\begin{array}{l}\text { Neurologiques } \\
\text { symptoms }\end{array}$ & $\begin{array}{l}\text { Headaches } \\
\text { Vertigo } \\
\text { Agitation }\end{array}$ & $\begin{array}{l}\text { Headaches } \\
\text { Vertigo } \\
\text { Agitation }\end{array}$ & $\begin{array}{l}\text { Headaches } \\
\text { Vertigo } \\
\text { Agitation }\end{array}$ \\
\hline $\begin{array}{l}\text { Neurovegetative } \\
\text { symptoms }\end{array}$ & & Mydriasis & Mydriasis \\
\hline $\begin{array}{l}\text { Respiratory } \\
\text { symptoms }\end{array}$ & & Dyspnea & \\
\hline $\begin{array}{l}\text { Evacuator } \\
\text { treatment }\end{array}$ & $\begin{array}{l}\text { Induced } \\
\text { vomiting }\end{array}$ & & $\begin{array}{c}\text { Induced } \\
\text { vomiting }\end{array}$ \\
\hline $\begin{array}{c}\text { Symptomatic } \\
\text { Treatment } \\
\end{array}$ & Yes & Yes & Yes \\
\hline Vigilance & Calm & & Restless \\
\hline Evolution & Deaths & Deaths & Deaths \\
\hline Circumstances & Accidental & Addition & \\
\hline
\end{tabular}

The average methanol value was $1,33 \mathrm{~g} / \mathrm{l}$. only one of the four bottles had a significant methanol value $217 \mathrm{~g} / 1$ (Table II and photo 1).

Table II: Doses of methanol in the methylated spirits products in the episode of methanol poisoning in the city of El-HAJEB, May 2017, analysed at CAPM-LAB

\begin{tabular}{|l|l|l|}
\hline Products & $\begin{array}{l}\text { Ethanol dose } \\
(\mathrm{g} / \mathrm{l})\end{array}$ & $\begin{array}{l}\text { Methanol } \\
\text { dose }(\mathrm{g} / \mathrm{l})\end{array}$ \\
\hline
\end{tabular}




\begin{tabular}{|l|l|l|}
\hline Product 1 & 317 & 217 \\
\hline Product 2 & 539 & 6 \\
\hline Product 3 & 693 & 0 \\
\hline Product 4 & 604 & 7 \\
\hline
\end{tabular}

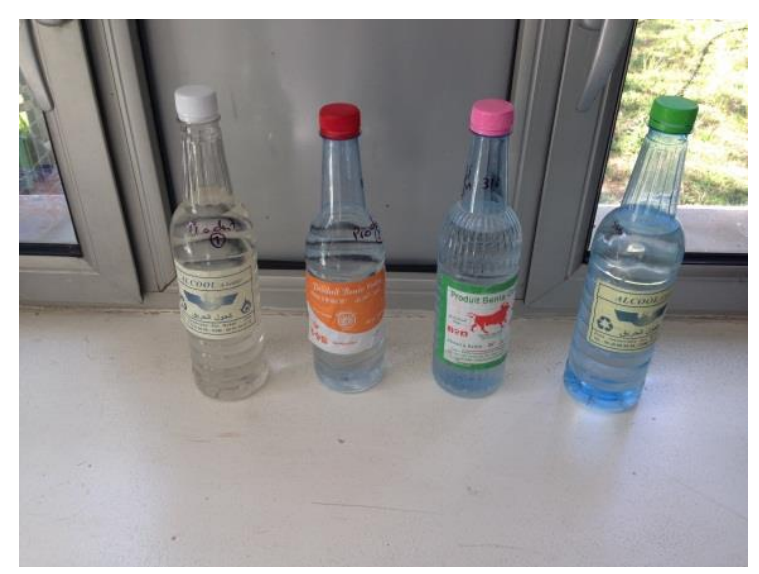

Fig 1: The four products incriminated in the methanol poisoning episode in the city of El-HAJEB, May 2017, analysed at CAPM-LAB

\section{Intoxication episode in Marrakech:}

The second investigation in the city of Marrakech, concerned three people, presented with digestive and neurological disorders following the consumption of counterfeit alcohol at the end of May 2017. The CAPM-LAB received the sample of only one patient who subsequently died. The value of methanolemia was $1,09 \mathrm{~g} / \mathrm{l}$.

Table III: Methanol and Ethanol concentration of the four patients

\begin{tabular}{|l|l|l|}
\hline Patient & $\begin{array}{l}\text { Methanolemia } \\
\mathbf{g} / \mathbf{L}\end{array}$ & $\begin{array}{l}\text { Ethanolemia } \\
\mathbf{g} / \mathbf{L}\end{array}$ \\
\hline Patient 1 & 0,7 & $<0,1$ \\
\hline Patient 2 & 1,94 & $<0,1$ \\
\hline Patient 3 & 1,35 & $<0,1$ \\
\hline Patient 4 & 1,09 & $<0,1$ \\
\hline
\end{tabular}

\section{Discussion}

The clinical picture of methanol intoxication is not specific, which can delay treatment and threaten the patient's vital prognosis, especially as there is a delay between intoxication and the onset of symptoms [10]. Indeed, ophthalmological damage is not always present. In addition, metabolic acidosis with increased anion gap and osmolarity is not constant [10]. Therefore, the determination of blood methanol makes it possible to diagnose intoxication and to start antidrug treatment as soon as possible.

The reference method for the determination of methanol is gas chromatography. This technique allows the determination of methanol and its metabolites as well as concomitantly absorbed or therapeutically injected ethanol. It is a specific and sensitive. The only drawback of the technique is the cost of the equipment, which is not available in all laboratories [9]. Other inexpensive and easy colorimetric methods for detecting methanol and other alcohols, particularly in saliva, have been developed but remain qualitative methods [9]. Measurement of serum formate by a simple enzymatic method is also a sensitive and specific indirect diagnostic method for methanol poisoning [11]. In Morocco, the CAPM-LAB has developed and validated a method for the determination of methanol and ethanol by CPG-FID in order to meet the expectations of clinicians in the management of intoxications by these alcohols, particularly during collective intoxications.

The interpretation of methanol results depends on the time of intoxication and the concomitant intake of ethanol. A high blood methanol level indicates recent severe intoxication or moderate intoxication with ethanol. A lower methanol level may be the result of a recent minimal intake or a severe but long-standing intoxication [7]. In general, a methanol concentration of more than $0,25 \mathrm{~g} / 1$ is considered toxic, and from 0,5 $\mathrm{g} / \mathrm{l}$ onwards, intoxication becomes severe. In our case series, methanolemia were high in cases of fatale intoxication (Table III, Table VI). Lethal dose has been reported as $1.2 \mathrm{~mL} / \mathrm{kg}$ [12].

The present study shows that the oral ingestion of illegal illegal alcoholic beverages spirits is a most common cause of acute methanol poisoning.

Table IV: Clinical manifestations

\begin{tabular}{|l|l|}
\hline $\begin{array}{l}\text { Methanol } \\
\text { concentration }\end{array}$ & $\begin{array}{l}\text { Clinical } \\
\text { Manifestations }\end{array}$ \\
\hline $\begin{array}{l}\text { Less than à 0,5 } \\
\mathrm{mg} / \mathrm{L}\end{array}$ & $\begin{array}{l}\text { Physiological } \\
\text { (feeding) }\end{array}$ \\
\hline $\begin{array}{l}\text { Less than à 0,2 } \\
\mathrm{g} / \mathrm{L}\end{array}$ & Asymptomatic \\
\hline From 0,5 g/L & $\begin{array}{l}\text { Central nervous } \\
\text { system damage }\end{array}$ \\
\hline Above $0,5 \mathrm{~g} / \mathrm{l}$ & $\begin{array}{l}\text { Serious } \\
\text { intoxication }\end{array}$ \\
\hline 1,5 to $2 \mathrm{~g} / 1$ & vital prognosis \\
\hline
\end{tabular}

It is a rare but potentially serious intoxication. The evolution of methanol intoxication is conditioned by the degree of acidosis and the time between exposure and the initiation of specific treatment, the prognosis being vital above $1.5 \mathrm{~g} / 1$ to $2 \mathrm{~g} / 1$ [13]. Patients have died from multivisceral failure.

Symptoms may present as early as few hours or up to 2 days post ingestion [14]

Another advantage of methanol testing is the indication of haemodialysis according to the criteria established by the experts in the consensus on the management of methanol poisoning. This, haemodialysis is indicated in cases where blood concentration methanol is greater than $50 \mathrm{mg} / \mathrm{dl}$ without anti-drug treatment, or greater than $70 \mathrm{mg} / \mathrm{dL}$ after treatment with fomepizole, or greater than $50 \mathrm{mg} / \mathrm{dL}$ after treatment with 
ethanol $[2,15]$. If ethanol is the antidote used, dialysis is recommended if the methanol level is above $20 \mathrm{mmol} / \mathrm{L}$ (60 mg/dL) [16].

Methanol can be responsible for rare but potentially serious intoxications. The first symptoms, sometimes minor at the beginning, and their latency of appearance, are linked to the formation of a toxic metabolite, formic acid, which can be the cause of the progressive installation of irreversible blindness.

Methanol itself is rather non-toxic and there is usually a latent period of about 12-24 hours from the ingestion of methanol to the occurrence of symptoms.

The determination of formic acid, a metabolite of methanol, in the blood is also of great interest in dating intoxication and confirming the diagnosis of cases seen late, but also in monitoring the evolution of intoxication. It is also worthwhile to repeat methanol and metabolite methanol determinations in order to monitor the evolution of intoxication under treatment [7]. Knowledge of the time elapsed since ingestion is very important for the interpretation of the result, unfortunately we were unable to obtain this data for our cases.

It should be noted that the simultaneous intake of ethanol maintains methanol concentrations by blocking the metabolism but reduces its toxicity.

A significant methanolemia can result from a recent severe intoxication or from a moderate intoxication but concomitant to the intake of ethanol which blocks the catabolism of methanol. Jones et al. (17) reported a fatality attributed to methanol poisoning with postmortem formate and methanol Concentrations of 12 and $790 \mathrm{mg} / \mathrm{dL}$, respectively. The authors noted that death was likely due to of the central nervous system depression associated with the extremely high methanol concentration.

The goal of medical intervention in methanol poisoning is to reduce blood concentrations of methanol and formic acid. The results from different treatments (fomepizole, hemodialysis, folic acid and ethanol) and the clinical evolution, depending on the time when the treatment began [18]. The contamination of illegal liquor with methyl alcohol might lead to an unintentional outbreak of methanol intoxication, increasing the prevalence rates reported in some studies [19].

\section{Conclusion and Outlook}

It is important of toxicology laboratory to have a methanol CPG method that allows the quantification of methanol and its metabolites as well as other alcohols and glycols, in an emergency situation to ensure rapid and appropriate management.

Methanol can cause a fatal intoxication that develops due to its easy accessibility in our country, its illegal production of illegal alcoholic beverages, or the use of people for pain relief in local treatments, as in this case.

In our laboratory, we have set ourselves the goal of developing methods for determination of methanol metabolites, but also of other alcohols and glycols, in order to help the clinician in his diagnostic and approach.

\section{References}

1. Zakharov S, Kotikova K, Vaneckova M, Seidl $Z$, Nurieva O, Navratil $T$ et al. Acute Methanol Poisoning: Prevalence and $\mathrm{Pr}$ edisposing Factors of Haemorrhagic and NonHaemorrhagic Brain Lesions. Basic Clin Pharmacol Toxicol. 2016;119(2):228-38.

2. Barceloux DG, Bond GR, Krenzelok EP, Cooper $\mathrm{H}$, Vale JA; American Academy of Clinical Toxicology Ad Hoc Committee on the Treatment Guidelines for Methanol Poisoning. American Academy of Clinical Toxicology practice guidelines on the treatment of methanol poisoning. J Toxicol Clin Toxicol. 2002; 40(4):415-46.

3. Liu JJ, Daya MR, Carrasquillo O, Kales SN: Prognostic factors in patients with methanol poisoning. J Toxicol Clin Toxicol 1998, 36:175181.

4. Hassanian-Moghaddam H, Pajoumand A, Dadgar SM, Shadnia S: Prognostic factors in methanol poisoning. Hum Exp Toxicol 2007, 26:583-586.

5. Hovda $\mathrm{KE}$, Hunderi $\mathrm{OH}$, Tafjord $\mathrm{AB}$, Dunlop $\mathrm{O}$, Rudberg $\mathrm{N}$, Jacobsen D: Methanol outbreak in Norway 2002-2004. Epidemiology, clinical features and prognostic signs. J Intern Med 2005, 258:181-190.

6. Chaoui H. L'intoxication aigue au méthanol : un risque méconnu ? Toxicologie Maroc - 4 1er trimestre $2010-15$.

7. Théfenne $H$, Turc J, Carmoi $T$, Gardet $V$, Renard C. Intoxication aiguë au méthanol : réflexion à partir d'un cas. Ann Biol Clin 2005; 63 (5):556-60.

8. Paasma $R$, Hovda KE, Tikkerberi $A$, Jacobsen D. Methanol mass poisoning in Estonia: outbreak in 154 patients. Clin Toxicol. 2007; 45(2):152-157.5.

9. Kraut JA. Diagnosis of toxic alcohols: limitations of present methods. Clin Toxicol (Phila). 2015; 53(7):589-595.

10. Kraut JA, Kurtz I. Toxic alcohol ingestions: clinical features, diagnosis, and treatment. Clin J Am Soc Nephrol. 2010; 3:194-201.

11. Hovda KE, Urdal P, and Jacobsen D. (2005). Increased serum formate in the diagnosis of methanol poisoning. Journal of Analytical Toxicology, 29, 586-8. 
12. Mégarbane B. Treatment of patients with ethylene glycol or methanol poisoning: focus on fomepizole. Open Access Emergency Med. 2010; 2:67-75.

13. Lamiable et al. Inoxication aiguë au méthanol, EMC-Toxicologie Pathologie 1(2004) 7-12.

14. Kraut J. Approach to the treatment of methanol intoxication. Am J Kidney Dis. 2016;68(1):161-7.

15. Roberts DM, Yates C, Megarbane B, et al. Recommendations for the role of extracorporeal treatments in the management of acute methanol poisoning: a systematic review and consensus statement. Crit Care Med. 2015; 43(2):461-472.

16. Jacobsen D and McMartin KE. (1986). Methanol and ethylene glycol poisonings. Mechanism of toxicity, clinical course, diagnosis and treatment. Medical Toxicology, 1, 309-34.

17. G.R. Jones, P.P. Singer, and K. Rittenbach. Relationship of methanol and formate concentrations in fatalities where methanol is detected. J. Forensic Sci. 52:1376-1382 (2007).

18. Bucaretchi F, Capitani EM, Madureira PR, Cesconetto DM, Lanaro R, Vieira RJ. Suicide attempt using pure methanol with hospitalization of the patient soon after ingestion: case report. Sao Paulo Med J. 2009; 127(2):108-10.

19. Md Noor J, Hawari R, Mokhtar MF, et al. Methanol outbreak: a Malaysian tertiary hospital experience. Int J Emerg Med. 2020;13(1):6. 